\title{
Situational Leadership Style Supports the Performance of Doctors in the Military Based Hospital
}

\author{
Anastasia Dessy Harsono, Ratna Indrawati, and Idrus Jus'at
}

\section{ABSTRACT}

\begin{abstract}
The doctor's performance played an important role in achieving the vision and mission of a hospital. Many factors affected performance, including leadership style, work environment, organizational learning, work motivation, work discipline and so on. This study aimed to analyze the influence of situational leadership style, work environment, organizational learning, and work motivation on performance. The research design used was quantitative analytic research with a causality approach. The data source was obtained in the form of primary data. Samples were a total sampling. Data analysis using Structural Equation Modeling (SEM) AMOS. The results of the research were situational leadership style, work environment, organizational culture and work motivation partially or simultaneously had a positive and significant effect on the performance of general practitioners. The findings of the study were that the situational leadership style and work environment had a positive and significant effect on organizational culture, work motivation and performance of general practitioners. The direct influence of the situational leadership style on the performance of general practitioners was greater than the work environment, organizational culture, and work motivation.
\end{abstract}

Submitted : February 26, 2021

Published : March 31, 2021

ISSN: $2507-1076$

DOI: $10.24018 /$ ejbmr.2021.6.2.780

Anastasia Dessy Harsono

Esa Unggul University, Jakarta, Indonesia. (e-mail: anastasia.bedahplastik@gmail.com) Ratna Indrawati*

Esa Unggul University, Jakarta, Indonesia. (e-mail: ratna.indrawati@esaunggul.ac.id) Idrus Jus'at

Esa Unggul University, Jakarta, Indonesia. (e-mail: idrus.jusat@esaunggul.ac.id)

*Corresponding Author

Keywords: situational leadership style, work environment, organizational learning, work motivation, performance of general practitioners.

\section{BACKGROUND}

The doctor's performance played an important role in achieving the vision and mission of a hospital. Many factors influenced performance, including: the ability of hospital management to carry out its managerial functions, work motivation, work discipline, the availability of adequate facilities and infrastructure, the existence of effective and efficient work mechanisms and a conducive working environment and climate.

The general practitioner was a human resource (HR) as the first pillar in the Emergency Room and patient services outside of working hours. Performance assessment is determined by several indicators: patient care, medical / clinical knowledge, practice-based learning and improvement, interpersonal and communication skills, professionalism, systems-based practice [1].

Based on the results of the pre-survey conducted at $\mathrm{X}$ hospital, 23 out of 30 general practitioners said that the performance of general practitioners (patient care, medical / clinical knowledge, effective communication, professionalism) saw examples from their leaders. They said that the desired leader is a leader who can direct, encourage and give confidence and can determine when to nurture and when to act decisively. Attachment to hospital rules and love of organization were also influential in carrying out daily services such as the presence of alert reports, emergency and inpatient services, carrying out orders for health support duties outside the hospital and being prepared for pandemic services outside of their routine duty areas.

Since 1977 until now, this hospital has been led by 25
Heads of Hospitals (Karumkit) alternately X hospital is currently fully accredited by JCI and KARS. Another phenomenon was the number of general practitioners (honorary, military and civil servants) was very less when compared to specialist doctors and all hospital personnel (100: 313: 2660). In this connection, the hospital has recruited honorarium staff for solutions to meet personnel needs. Until now, the percentage of honorary general practitioners has reached $65 \%$. It turned out that $50 \%$ of the honorary general practitioners received have a relationship with hospital employees and $75 \%$ have a desire to get a recommendation to continue specialist education.

\section{LITERATURE REVIEW}

According to Robbins [2], performance is a measure of work results which illustrates the extent to which a person's activities carry out tasks and strive to achieve the goals set. Meanwhile, based on the definition of Moeheriono [3] it can be concluded that performance is the work that can be achieved by a person or group of people in an organization both quantitatively and qualitatively, in accordance with their respective authorities and responsibilities, in an effort to achieve organizational goals. concerned legally, does not violate the law and is in accordance with morals and ethics. The performance of health workers is a very important issue to study in order to maintain and improve health development. Many factors can affect performance, namely individual factors, psychological factors and organizational factors. The study of performance provides clarity on the factors that affect individual and organizational performance. 
Leadership is very important in determining the direction of success of an organization, defined as "a process of social influence where the leader seeks voluntary participation from subordinates in an effort to achieve organizational goals [4]. The behavior of leaders in the organization seeks to improve the quality of themselves and their subordinates. The role of the leader to empower his subordinates is expected to give the organization a chance to exist and win in every competition. The situational leadership style includes directing (directing), coaching (training), supporting (encouraging) and delegating (delegating) [5].

Although X hospita is an asset of the Army, X hospital is also a unique institution, which does not only provide health services to the general public but also carry out health support in military activities. A leader cannot apply authoritarian leadership, but must see the situation at hand. This consequence is important considering that the majority of general practitioners are honorary. Situational leadership style can make the right decisions at the right time according to the situation at hand.

\section{RESEARCH MODEL}

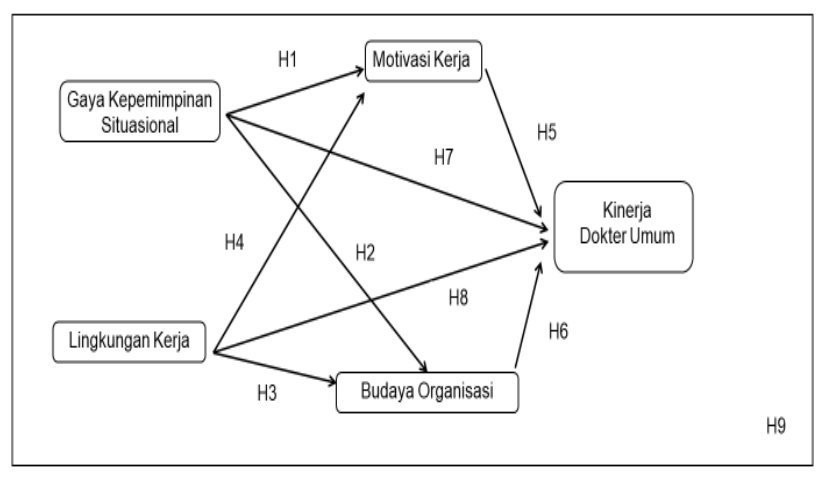

Fig. 1. Research Model.

\section{RESEARCH HYPOTHESIS}

H1: There is a relationship between leadership style and work motivation of general practitioners at X Hospital.

$\mathrm{H} 2$ : There is a relationship between leadership style and organizational culture at X Hospital.

H3: There is a relationship between the work environment and organizational culture at X Hospital.

H4: There is a relationship between the work environment and the work motivation of general practitioners at $\mathrm{X}$ Hospital.

H5: There is a relationship between work motivation and the performance of general practitioners at X Hospital.

H6: There is a relationship between organizational culture and the performance of general practitioners at X Hospital.

H7: There is a relationship between the leadership style and the performance of the X Hospital general practitioners.

H8: There is a relationship between the work environment and the performance of general practitioners at X Hospital.

H9: There is an influence of situational leadership style, work environment, organizational culture and work motivation with the performance of general practitioners at $\mathrm{X}$ Hospital.

\section{RESEARCH Methods}

This research is a quantitative analytic study with a causality approach. The sample used is total sampling. Data collection techniques by distributing questionnaires (Likert scale) in hardcopy and google-form form to 100 respondents. The data obtained were tested for validity and reliability.

The validity test uses Pearson Product Moment Correlation, it is said to be valid if the calculated $r$ value> $r$ table. Data from 30 respondents were taken for validity testing. Invalid questionnaire items were not included in further analysis.

The reliability test used the Cronbach Alpha $(\alpha)>0.6$ test, it was found that all of the research variables were reliable. All variables tested for reliability were found to be eligible. Data analysis in this study used the SEM-AMOS model.

\section{RESULTS AND DISCUSSION}

\section{A. Results}

\section{Descriptive Analysis}

Of the 100 respondents who were studied at X Hospital, Central Jakarta, obtained a ratio of female to male respondents 1.9:1. The largest age group was in the 25-30 years age group as many as 67 people $(67 \%)$. S1 graduates are the largest group, namely 94 people $(94 \%)$. Most of the employment status is honorary $(65 \%)$. Based on the length of work, it was found that the largest group was with a service period of $<5$ years as much as $79 \%$.

The results of descriptions of respondents' answers about attitudes in behavior are shown in the behavior matrix in Table I as follows:

TABLE I: MATRIX OF RESPONDENTS' RESPONSES AT X HOSPITAL CENTRAL JAKARTA

\begin{tabular}{|c|c|c|c|c|c|}
\hline \multicolumn{6}{|c|}{ CENTRAL JAKARTA } \\
\hline \multirow{2}{*}{ No. } & \multirow{2}{*}{ Variable } & \multicolumn{4}{|c|}{ Respondent Response Position } \\
\hline & & Low & Moderate & High & Behavior \\
\hline 1 & $\begin{array}{c}\text { Situational leadership } \\
\text { style }\end{array}$ & & & $\sqrt{ }$ & Satisfied \\
\hline 2 & Work environment & & $\sqrt{ }$ & & $\begin{array}{c}\text { Comfortable } \\
\text { enough }\end{array}$ \\
\hline 3 & Organizational culture & & & $\sqrt{ }$ & Support \\
\hline 4 & Work motivation & & & $\sqrt{ }$ & High \\
\hline 5 & $\begin{array}{c}\text { General practitioner } \\
\text { performance }\end{array}$ & & & $\sqrt{ }$ & Good \\
\hline
\end{tabular}

From Table I above, the respondents' responses to the situational leadership style, work environment, organizational culture, work motivation and performance of general practitioners are obtained. The results showed that all variables had a positive response. When examined more deeply through the questionnaire statement items, there is still a response that is not optimal. In the situational leadership style variable, it is known that respondents think that their leaders sometimes say something that hurts their feelings, they do not consider their employees' personal interests. Assessment of work environment variables, respondents feel boredom because there is no periodic rotation. In terms of organizational culture, respondents think that the leadership does not consider time for the personal benefit of employees and their families. In terms of work motivation, most of them think the material is not the main thing. These three factors can reduce the work discipline of the people in the 
organization. The performance variable states that general practitioners are sometimes given education and training that is not according to their interests.

\section{Normality test}

The normality test using the AMOS program aims to determine whether the data obtained is normally distributed or not. In this study, the data was said to be normally distributed if the value of $\mathrm{cr} \pm 2.58$ and none of them became outliers ( $\mathrm{p}$-value $<0.001$ ) in the outlier test.

Table II shows that the value in the cr (Skewness) column is in the \pm 2.58 value range, which means that the research data obtained is normally distributed.
Table III shows the results of the outlier test in which no single observation had a p-value $<0.001$ or there were no outliers. This shows that the data obtained is normally distributed.

Table IV shows that the value of X2 - Chi Square is 158.453 and the probability is $p=0.082$. The probability above 0.05 indicates that Ho, which states that there is no difference between the sample covariance matrix and the estimated population covariance matrix, is acceptable. This means that the sample covariance matrix with the estimated population covariance matrix is the same, so the model is declared fit.

TABLE II: NORMALITY TEST RESULTS

\begin{tabular}{ccccccc}
\hline Variable & min & $\max$ & skew & c.r. & kurtosis & c.r. \\
\hline Y6 & 2.200 & 5.000 & -0.203 & -.830 & 0.608 & 1.241 \\
Y4 & 2.600 & 5.000 & -0.431 & -1.760 & 0.404 & 0.825 \\
Y3 & 2.200 & 5.000 & -0.422 & -1.721 & 0.563 & 1.149 \\
Y1 & 2.600 & 5.000 & -0.114 & -.465 & 0.102 & 0.208 \\
X3.4 & 2.250 & 5.000 & -0.193 & -.787 & 0.256 & 0.522 \\
X3.3 & 2.200 & 5.000 & -0.353 & -1.440 & -0.018 & -0.038 \\
X3.2 & 2.750 & 5.000 & -0.278 & -1.136 & -0.322 & -0.656 \\
X3.1 & 2.400 & 5.000 & -0.267 & -1.090 & 0.072 & 0.146 \\
X4.3 & 2.500 & 4.800 & 0.160 & .652 & -0.496 & -1.013 \\
X4.2 & 2.000 & 5.000 & -0.407 & -1.663 & -0.038 & -0.079 \\
X4.1 & 2.167 & 5.000 & -0.080 & -.326 & 0.368 & 0.751 \\
X2.1 & 2.200 & 5.000 & 0.072 & .296 & -0.149 & -0.304 \\
X2.2 & 2.600 & 5.000 & 0.538 & 2.196 & -0.328 & -0.669 \\
X2.3 & 2.000 & 4.750 & -0.259 & -1.057 & -0.204 & -0.417 \\
X2.4 & 2.167 & 5.000 & 0.259 & 1.059 & 0.391 & 0.799 \\
X1.4 & 2.667 & 5.000 & 0.095 & .389 & -0.217 & -0.443 \\
X1.3 & 2.800 & 4.800 & 0.245 & 1.002 & -0.040 & -0.081 \\
X1.2 & 2.000 & 5.000 & -0.605 & -2.470 & 1.781 & 3.636 \\
X1 & 2.200 & 5.000 & -0.628 & -2.564 & 0.165 & 0.338 \\
Multivariate & & & & & 47.375 & 8.385 \\
\hline
\end{tabular}

TABLE III: OUTLIER TEST RESULTS

\begin{tabular}{cccc}
\hline \multicolumn{4}{c}{ TABLE III: OUTLIER TEST RESULTS } \\
\hline Observation number & $\begin{array}{c}\text { Mahalanobis } \\
\text { d-squared }\end{array}$ & $\mathrm{p} 1$ & $\mathrm{p} 2$ \\
\hline 17 & 42,115 & 0.002 & 0.157 \\
69 & 39,695 & 0.004 & 0.051 \\
2 & 39,306 & 0.004 & 0.008 \\
37 & 36,778 & 0.008 & 0.011 \\
83 & 36,200 & 0.010 & 0.003 \\
36 & 34,484 & 0.016 & 0.006 \\
61 & 32,580 & 0.027 & 0.018 \\
100 & 32,319 & 0.029 & 0.008 \\
96 & 32,268 & 0.029 & 0.003 \\
86 & 31,304 & 0.037 & 0.004 \\
84 & 31,089 & 0.039 & 0.002 \\
87 & 30,542 & 0.045 & 0.002 \\
\hline
\end{tabular}

TABLE IV: GOODNESS OF FIT TEST RESULTS

\begin{tabular}{cccc}
\hline Goodness of fit & Cut-off Value & Model Results & Information \\
\hline \multirow{3}{*}{ Keep the value small with } \\
- chi square & $\mathrm{df}=135$ table value $=$ & 158,453 & Good \\
& 163.11 & 0.082 & Good \\
\hline Probability & $\geq 0.05$ & 1,456 & Good \\
Cmin / DF & $\leq 2$ & 0.869 & Marginal \\
GFI & $\geq 0.90$ & 0.042 & Good \\
RMSEA & $\leq 0.079$ & 0.815 & Marginal \\
AGFI & $\geq 0.90$ & 0.976 & Good \\
TLI & $\geq 0.90$ & 0.981 & Good \\
CFI & $>0.90$ & & \\
\hline
\end{tabular}

\section{Hypothesis test}

The relationship between variables, both direct and indirect, was carried out using the SEM-AMOS program. The results can be seen on the figure below.

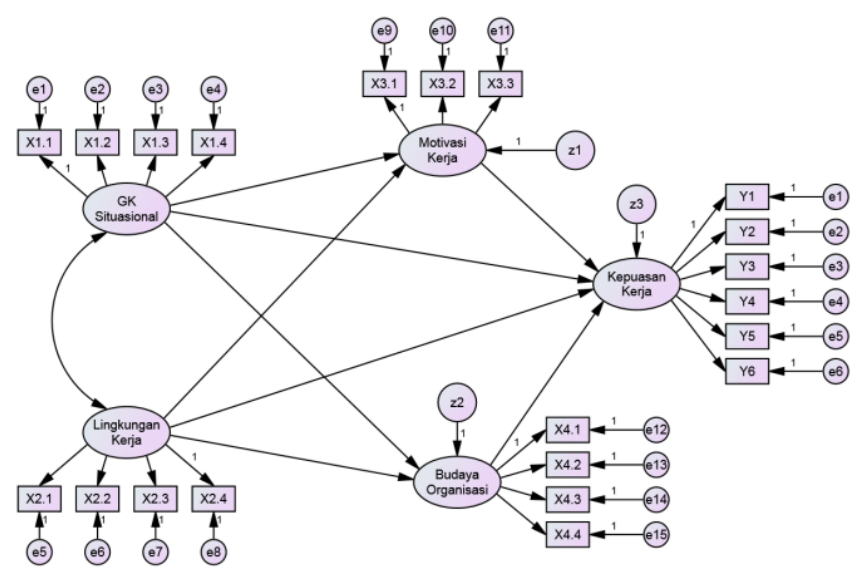

Fig. 2. Research Construction Model.

\section{B. Discussion}

1. The influence of leadership style on work motivation

Hypothesis testing conducted in this study shows that there is a positive and significant influence of situational leadership style on work motivation by $54.1 \%$ (p-value <0.05). Based on the analysis of the distribution of respondents with the three box method, it shows that most of the indicators of situational 
leadership provide a perception of high index values, with the highest index value on encouraging indicators, namely "require employees to follow regulatory standards.

This is supported by a high assessment of work motivation with the highest index value found in the superior's motive indicator, namely "colleagues help in completing tasks".

This means that the general practitioners at X hospital, Central Jakarta feel thatA leader will be effective if his leadership style is in accordance with the situation seen from his competence and commitment, so this condition has an effect to generate encouragement from within and from outside the individual in an effort to achieve goals in this case work.

The results of the study support the opinion of Grujicic [6], "the relationship between leadership style and work motivation is very close". The leadership style of a leader can affect the work motivation of his subordinates, therefore, leadership style is needed in an organization. Meanwhile, according to Mc Shane [7] and Kreitner \& Kinicki [4], states that "the leadership style applied by a leader or a manager in an organization can create harmonious integrity and encourage employee morale to achieve maximum goals". Looking at the two previous definitions, it can be concluded that the work motivation of a subordinate is highly dependent on the ability of a leader through his leadership style to influence employees to act in accordance with employee expectations from the organization.

The opinion of the researchers is in line with the research results of Lynch and Mert [8], Fatimah and Wahyuni [9], Hasiolan and Reniyati [10], Firmanyah and Erika [11] are in accordance with the theory and expert opinion that leadership and motivation are two different things, must have a link in the context of work and interaction between people, and leadership is a human factor that binds a group together and gives it motivation towards certain goals, both in the short and long term. This means that leadership and motivation have a strong bond / relationship.

2. The influence of leadership style on organizational culture

Hypothesis testing conducted in this study shows that there is a positive and significant direct effect of transformational leadership on organizational culture $(\mathrm{p}<0.05)$. Based on the estimated value of the situational leadership style, it has a $50.2 \%$ influence on organizational culture, the remaining $49.8 \%$ is influenced by other variables, it can be concluded that the situational leadership style has a positive and significant effect on organizational culture.

Based on the analysis of the distribution of respondents using the three box method, it shows that most of the indicators of situational leadership provide a perception of high index values, with the highest index value found in encouraging indicators, namely "require employees to follow regulatory standards."This is supported by a high assessment of organizational culture with the highest index value found on the Femininity and Masculinity indicator, which is" proud because it can make a real contribution to the success of the hospital and the surrounding community". This means that the general practitioners at X hospital, Central Jakarta feel thatA leader will be effective if his leadership style is in accordance with the situation seen from his competence and commitment, so that the doctor's assumptions are implicitly accepted by the group and determine how the group feels, thinks and creates in a diverse environment.

The research results are in accordance with the theory Robbins [12], which states that organizational culture is a framework that guides daily behavior and makes decisions for employees and directs their actions to achieve organizational goals. The research of Xiaoqiu [13], Mufidah \& Issroviatiningrum [14], Putra and Hamid [15] proves that the leadership style possessed by managers in managing, supporting and implementing clinical supervision and the existence of an organizational culture that applies in a hospital will have an impact on hospital service quality. Thus leadership style and organizational culture are related because there is no leader who is independent from culture, meaning that a good leadership style makes a good organizational culture [16].

3. The influence of the work environment on organizational culture

Hypothesis testing conducted in this study shows that there is a positive and significant influence of the work environment on organizational culture, namely $(\mathrm{p}<0.05)$. Based on the estimated value of the work environment, it has a $52.6 \%$ effect on organizational culture, the remaining $47.4 \%$ is influenced by other variables, it can be concluded that the work environment has a positive and significant effect on organizational culture.

Based on the distribution analysis of respondents using the three box method, it shows that most of the indicators of the work environment provide a perception of a moderate index value, with the highest index value found in the regulatory indicator is "always obey the warnings about environmental cleanliness on the hospital posters."

This is supported by a high assessment of organizational culture with the highest index value found on the Femininity and Masculinity indicator, which is "proud because it can make a real contribution to the success of the hospital and the surrounding community". This means that the general practitioners at $\mathrm{X}$ hospital, Central Jakarta feel thatthe surrounding conditions that affect where we work, both physical and psychological conditions that affect the completion of tasks, so that the doctor's assumptions are implicitly accepted by the group and determine how the group feels, thinks and creates in various environments.

The work environment greatly affects employees in carrying out their duties. Working conditions that are comfortable, safe and supported by a conducive organizational culture will make employees excited and passionate about work, in this case a positive influence on their performance, reduce the possibility of mistakes in assignments and increase work productivity [17]. This is in accordance with the research findings of Pradeep [18], Yulianti [19], Putra and Hamid [15].

The implementation of service practices will be carried out in a professional manner with the support of a conducive work environment and the prevailing organizational culture, namely by better understanding and applying abilities responsibly in empowering medical personnel.

\section{The influence of the work environment on work motivation}

Hypothesis testing conducted in this study shows that there is a positive and significant effect of the work environment 
on the work motivation of doctors $(\mathrm{p}<0.05)$. Based on the estimated value of the work environment, it has a $53.4 \%$ effect on the work motivation of doctors, the remaining $46.6 \%$ is influenced by other variables, it can be concluded that the work environment has a positive and significant effect on organizational culture.

Based on the analysis of the distribution of respondents using the three box method, it shows that most of the indicators of the work environment give a moderate perception of the index value, with the highest index value found in the regulatory indicator, namely "always obeying the warnings about environmental cleanliness on the hospital posters."

This is supported by a high assessment of the work motivation of the lecturers with the highest index value found in the superior motive indicator, namely "Colleagues help in completing assignments". This means that the general practitioners at $\mathrm{X}$ hospital, Central Jakarta feel that the surrounding conditions that affect where we work, both physical and psychological conditions that affect the completion of the task, so that this condition has the effect of generating encouragement from within and from outside the individual in an effort to achieve goals, in this case work.

The results of the study support the theory put forward by Schultz [17] which states that the quality of the work environment concerns the physical and psychological work environment. The physical work environment is a work environment that employees can recognize with the senses, for example, work places, tools and infrastructure, while the psychological work environment is a work environment that employees cannot recognize with the senses, such as relationships with superiors and coworkers. The results of the study also support the research results of Jain [20], Yulianti [19], Danardono I. \& Pribadi F. [21] which states that companies that want to create performance for employees must pay attention to the company's work environment. so that employees have work motivation and enthusiasm to carry out their duties.

\section{Effect of work motivation on performance}

Hypothesis testing conducted in this study showed that there was a positive and significant direct effect of work motivation on the performance of general practitioners $(\mathrm{p}<0.05)$. Based on the estimated value of work motivation has an effect of $26.5 \%$ on the performance of general practitioners, the remaining $73.5 \%$ is influenced by other variables, it can be concluded that work motivation has a positive and significant effect on the performance of general practitioners.

Based on the analysis of the distribution of respondents using the three box method, it shows that most of the indicators of work motivation give the highest perception of the index value found in the superior's motive indicator, namely "Colleagues help in completing tasks". This is supported by a high assessment of the performance of general practitioners with the highest index value found in the Medical / Clinical Knowledge indicator, namely "want to continue to develop themselves."

This means that the general practitioners at $\mathrm{X}$ hospital, Central Jakarta feel thatHigh motivation given by the hospital is indicated by the existence of satisfactory motives, hopes, and rewards so as to generate encouragement from within and from outside the individual in an effort to achieve goals, in this case work, it will affect the performance of good general practitioners whereThe results of this work have described a person's activities in carrying out tasks and trying to achieve in accordance with the goals set.

The results of the study support the theory raged by Cormick [22] which states that work motivation is the basic impetus that moves a person to work in accordance with his inner motivation. This involves both individual factors and organizational factors. Individual ones are needs, goals, attitudes, and abilities, while organizational ones are pay, job security, fellow employees (co workers), supervision, praise (praise), and the job itself (job itself). The results of the study support the research of Geckil [23], Danardono I. [21], Wardini [24] stated that with employee motivation, their needs are met, so that performance will emerge which has a positive impact on their performance.

6. The influence of organizational culture on performance Hypothesis testing conducted in this study showed that there was a positive and significant influence of organizational culture on the performance of general practitioners $(\mathrm{p}<0.05)$. Based on the estimated value of organizational culture, it has an effect of $30.8 \%$ on the performance of general practitioners, the remaining $69.2 \%$ is influenced by other variables, then

It can be concluded that organizational culture has a positive and significant effect on the performance of general practitioners.

Based on the analysis of the distribution of respondents using the three box method, it shows that most of the indicators of organizational culture giving the highest index value are in the indicators of Femininity and Masculinity, namely "proud because they can make a real contribution to the success of the hospital and the surrounding community". This is supported by a high assessment of the performance of general practitioners with the highest index value found in the Medical / Clinical Knowledge indicator, namely "want to continue to develop themselves."This means that the general practitioners at X hospital, Central Jakarta feel the values held by the people in the X hospital, Central Jakarta as appropriate, it will affect the performance of a good general practitioner where The results of this work have described a person's activities in carrying out tasks and trying to achieve in accordance with the goals set.

The results of the study support the theory raged by Robbins [12] which states that organizational culture is a set of assumptions or belief systems, values, and norms developed within the organization which are used as behavioral guidelines for its members to overcome external and internal adaptation problems.

The results of the study support the research of Mujeeb [25], Lousyiana [26], Wahyuningsih, Nuraina, and Amah [27] which proves that organizational culture affects work productivity in hospitals, due to activities that includes work freedom in completing work, mutual tolerance and mutual respect for both superiors and subordinates as well as upholding the family values that have been fostered by the hospital, thereby improving employee performance.

7. The influence of situational leadership style on performance

Hypothesis testing conducted in this study showed that 
there is a positive and significant influence of situational leadership style on the performance of general practitioners $(\mathrm{p}<0.05)$. Based on the estimated value of the situational leadership style, $31.3 \%$ influence the performance of general practitioners, the remaining $68.7 \%$ is influenced by other variables, it can be concluded that the situational leadership style has a positive and significant effect on the performance of general practitioners.

Based on the analysis of the distribution of respondents using the three box method, it shows that most of the indicators for the situational leadership style indicate that most of the indicators of the situational leadership style give the perception that the highest index value is found in encouraging indicators, namely "require employees to follow regulatory standards."This is supported by a high assessment of the performance of general practitioners with the highest index value found in the Medical / Clinical Knowledge indicator, namely"want to continue to develop themselves."This means that the general practitioners at $\mathrm{X}$ hospital, Central Jakarta feel that the hospital leadership has a good leadership style so that they are able to order, direct, encourage and delegate tasks to their subordinates., and this will affect the performance of good general practitioners where the results of this work have described a person's activities in carry out tasks and try to achieve in accordance with the objectives set.

The results of the study support the theory put forward by Blanchard [5] which states that one of the achievements of the leadership style is performance, where the leadership style plays an important role in influencing performance at both the superior and subordinate levels. Hospitals with different types and status of ownership will affect the leadership style and performance. The results of the study support the research of Ghazzawi [28], Firmansyah et al [29], Lousyiana, and Harlen [26], which states that effective leadership and employee performance are two factors that have been considered the basis for the success of an organization. A good leader is able to provide direction for the organization and its followers to lead to achieving the desired goals.

8. The influence of the work environment on performance

Hypothesis testing conducted in this study shows that there is a positive and significant effect of the work environment on the performance of general practitioners $(\mathrm{p}<0.05)$. Based on the estimated value of the work environment, $27.4 \%$ influence on the performance of general practitioners, the remaining $72.6 \%$ is influenced by other variables, it can be concluded that the situational leadership style has a positive and significant effect on the performance of general practitioners.

Based on the analysis of the distribution of respondents using the three box method, it shows that most of the indicators of the work environment show that most of the work environments provide the perception that the highest index value is in the regulatory indicator, namely "always obey the warnings about environmental cleanliness on the hospital posters." This is supported by a high assessment of the performance of general practitioners with the highest index value found in the Medical / Clinical Knowledge indicator, namely "want to continue to develop themselves.". This means that general practitioners at RS X, Central Jakarta feel that the environmental conditions are quite comfortable, such as the physical condition of the room, the psychological atmosphere in which they work, the length of time or temporary work and the regulations / procedures applied in this hospital., and this will affect the performance of general practitioners good where The results of this work have described a person's activities in carrying out tasks and trying to achieve in accordance with the goals set.

The results of the study support the theory put forward by Schultz [17] which states that the work environment is everything that is around workers and can affect themselves in carrying out their duties. Meanwhile, a conducive work environment can make employees comfortable to work. The results of the study support the research of Mangkunegara [30], Sari [31], Yulianti [19] who found that work environment conditions will create performance, because it can increase employee excitement and morale. The quality of the work environment concerns the physical and psychological work environment.

The physical work environment is a work environment that can be recognized by the senses by employees, for example work places, tools and infrastructure,

9. Influence Situational Leadership Style, Work Environment, Organizational Culture, Work Motivation on General Practitioner Performance

Hypothesis testing conducted in this study showed that there was a simultaneous influence between Situational Leadership Style, Work Environment, Organizational Culture, Work Motivation on General Practitioners' Performance, as evidenced by the assessment of Chi Square $=158.453$ with $\mathrm{p}=0.082(\mathrm{p}>0.05)$ yang means that the model has met the goodness of fit criteria.

Based on the analysis of the distribution of respondents using the three box method of responding to the responses of respondents to the situational leadership style, work environment, organizational culture, work motivation and performance of general practitioners. The situational leadership style given by $\mathrm{X}$ hospital, Central Jakarta is considered satisfactory by doctors, supported by a comfortable working environment, organizational culture, work motivation and general practitioner performance have been considered good.

Leadership and organizational culture are like two sides of the same coin. Both of them dance with each other to instil values in their followers, so that they can walk together to achieve organizational goals. The leader's vision can be successful if followers share the same thoughts.

They believe and believe that their mission is solely to achieve organizational success. Research conducted by Alrawahi [32] in The Effect of Situational Leadership style, Work Environment and Work Motivation on the Employee's concluded that situational leadership, work environment and work motivation have a significant relationship to employee performance. A similar research conducted by Dousin [33] states that work motivation and organizational culture greatly influence the performance of doctors and nurses in Malaysia. Meanwhile, according to Tasneem [34], the performance of health workers will improve the quality of services provided to consumers.

\section{Research Findings}

Situational leadership style and work environment have a 
positive and significant effect on organizational culture, work motivation and performance of general practitioners. This means that the situational leadership style will be able to influence, motivate and make others able to contribute and seek the participation of subordinates towards achieving goals in order to realize organizational goals through ways of ordering, directing, encouraging and delegating. This is supported by a comfortable working environment such as the physical condition of the room, the psychological condition of the work, the temporary working conditions and the supporting regulations so that it will be able to influence the completion of general practitioners' duties.

The creation of a situational leadership style and a good work environment will certainly be Being able to create a conducive organizational culture will make employees excited and passionate about work, in this case it will have a positive influence on their performance, reduce the possibility of mistakes in assignments and increase work productivity.

Another result is that organizational culture and work motivation can directly improve the performance of general practitioners. These findings are consistentwith theory Robbins [12], shows that the conditions of good organizational culture and high motivation are given by subordinates, so that the belief system, values, and norms developed in this hospital will be used as behavior guidelines for doctors to overcome external and internal adaptation problems, so as to improve the performance of doctors.

\section{Research Limitations}

Many of the respondents worked less than 1 year at the $\mathrm{X}$ hospital in Central Jakarta so that they did not have a good adaptation to the conditions of the work environment, and this was evident from the assessment that was still sufficient / moderate in the work environment.

This study did not take into account the workload, fatigue, focus of the employees when filling in, because the questionnaires were distributed while they were working and filled out between them.

\section{CONCLUSIONS, IMPLICATIONS AND SUGGESTIONS}

\section{A. Conclusion}

Situational leadership style and work environment have a positive and significant impact on the performance of general practitioners directly and through variables of organizational culture and work motivation.

Organizational culture and work motivation can directly improve the performance of general practitioners

\section{B. Implications}

The study found that the situational leadership style is good for use in military-based hospitals. This is in line with the 8 mandatory TNI which is guided by the slogan 'ing ngarso sung tulodho, ing madya mangun karso, tut wuri handayani' (in front of giving an example, in the middle of building the will, behind giving encouragement and influence). In this case the leader must be able to behave and act to see the situation and conditions that develop in the field. Even though $\mathrm{X}$ hospital is part of a military organization, the authoritarian leadership style which is one-way from top-down, will not guarantee the hospital can develop forward following the changes and demands of the surrounding environment. Hospitals from a business point of view must be able to compete with other private hospitals to increase their income without leaving their main duties in serving and supporting the health of military personnel and civil servants and their families.

To make the hospital management more effective in motivating subordinates so that they are able to delegate authority in handling emergencies, disasters, pandemics according to their competence, and encourage them with words that consider the personal feelings of general practitioners. This is important because these aspects are still considered low.

It is necessary to improve the physical facilities of the room, such as periodic maintenance of health facilities every year, adequate sunshine, and a more ergonomic interior with clean air circulation. In addition, work rotation and tempo need to be considered in order to be more varied and avoid feeling bored to prevent fatigue at work.

There needs to be an evaluation of the quality program that is being carried out including internal and external evaluations, behavior improvement and learning that have an effect on improving the organizational culture of the hospital, so that good communication and closeness between hospital officials and general practitioners is established. Besides, the workplace atmosphere must be able to reduce the level of stress and tension felt by general practitioners.

In motivating the performance of general practitioners, it is important to pay attention to the salary factor, so that they can work more comfortably, without having to do a lot of additional activities outside the hospital to increase their income.

In addition, it is necessary to provide awards for general practitioners so that they are more loyal and work hard for the advancement of the hospital, including providing recommendations for specialization education and candidates for civil servants for doctors who are still on honorarium.

\section{Suggestion}

The managerial ranks strive for the hospital to improve the quality of good situational leadership, namely leadership that is able to properly direct, encourage and delegate duties and responsibilities.

The hospital strives for a learning behavior system that motivates them to take opportunities and provide opportunities and support for general practitioners who want to develop themselves and improve their skills by following education and training in accordance with their fields.

Hospital health facility management to redesign doctors' offices with adequate lighting and paint the walls according to the needs of each unit. With the new work atmosphere, it is hoped that it can improve the psychology of working doctors.

Hospital management strives to perform rotation of doctor assignments with different duties and responsibilities. This is to avoid boredom and as a means of increasing experience.

Hospitals provide opportunities for general practitioners to rest according to their time. This can function as relieving fatigue and boredom at work. It is expected that with the new freshness, performance can increase. 
The management strives to provide rewards and incentives for good-performing general practitioners, thereby encouraging their loyalty. Conversely, strive to provide punishment for workers who do not contribute to hospital activities.

Building a hospital culture through good conditions and information systems, for example by improving and refining the hospital information system (SIMRS) and prescribing online into an integrated system, so that the results of reports from supporters can be read directly by doctors.

Hospital financial management needs to make innovations and improve the medical service management system so that it is more transparent and distributed quickly so that members are willing to survive and serve their organization.

\section{ACKNOWLEDGMENTS}

The author expresses his highest appreciation and thanks to Dr. dr. Ratna Indrawati, M.Kes and Idrus Jus'at, Ph.D as their supervisor and Dr. Rokiah Kusumapradja, SKM., MHA as the head of the Esa Unggul University Hospital Administration Master's study program, who has provided support, assistance and motivation since the lecture began until the writing of this thesis.

\section{REFERENCES}

[1] Joint Commission International. 2014. Joint Commission International Accreditation Standards for Hospitals. 5 Edition. JCI. USA.

[2] Robbins, S. (2006). Perilaku Organisasi. Jakarta: PT. Indeks Kelompok Gramedia.

[3] Moeherionov (2012). Pengukuran Kinerja Berbasis Kompetensi Edisi Revisi. Penerbit: Rajagrafindo Persada. Jakarta.

[4] Kreitner R. Kinicki A. (2010) Organizational Behavior, 9th edition New York, Mc Graw Hill.

[5] Blanchard, Ken. (2019) Situational Leadership II The Model; http://www.kenblanchard.com/solutions/onetoone/slii_model/Default. asp?print.

[6] Grujicic, Maja \& Sipetic-Grujicic, Sandra \& Cvejin, Mirjana \& Novakovic, Budimka \& Jovicic Bata, Jelena. (2016). Differences in work motivation and job satisfaction between physicians and nurses.

[7] Mc Shane, Glinov, V (2015) Organizational Behavior, 5 th edition, New York, Mc.Graw Hill.

[8] Lynch, Mert. (2012). A guide to effective school leadership theories. Routledge.

[9] Fatimah R., Wahyuni, I., Widjasena B. (2016). Pengaruh Kepemimpinan dan Motivasi Kerja Terhadap Kinerja Perawat Rawat Jalan Rumah Sakit Islam Harapan Anda Tegal, Jurnal Kesehatan Masyarakat, 4(3), 614-622.

[10] Hasiolan, L., B., Reniyati (2017). Analisis Pengaruh Motivasi, Lingkungan Kerja dan Kepemimpinan Terhadap Kinerja Karyawan (Studi Kasus Pada Rumah Sakit Umum Daerah Kota Semarang).

[11] Firmansyah, M. A., \& Mochklas, M. (2020, May). The Effect of Leadership Style and Financial Incentives on Employee Performance. In 1st Borobudur International Symposium on Humanities, Economics and Social Sciences (BIS-HESS 2019). Atlantis Press.

[12] Robbins. (2002). Organizational Behavior, Alih Bahasa Dr. Handayani Pujoatmoko, Jakarta; PT. Prenhaltindo.

[13] Xiaoqiu. (2015). Doctors' Job Satisfaction, Organizational Citizenship Behavior and Burnout - An Empirical Study in China's Public Hospital. ISCTE.

[14] Mufidah, SZ, Issroviatiningrum, R., Sari, DWP (2018). Hubungan Gaya Kepemimpinan Dengan Budaya Organisasi Di Rumah Sakit Islam Sultan Agung Semarang, Unissula Press (ISBN 978-602-114569-2), 83-89.

[15] Putra, KR, Hamid, AY, Mustikasari (2007). Pengaruh Lingkungan Kerja Perawat Terhadap Pelaksanaan Praktek Keperawatan di Rumah Sakit Umum Dr.Saiful Anwar Malang tahun 2006, Jurnal Kedokteran Brawijaya, 23(1), 50-54.

[16] Luna. (2008). The Relationship between Emotional Intelligence,
Leadership Styles, and Burnout in NCAA Coaches. The Sport Journal.

[17] Schultz. (2017). Transformational leadership as a mediator in the relationship between satisfaction with remuneration and the retention of artisans in the military. SA Journal of Human Resource Management, 15, 9.

[18] Pradeep. (2020). Identifying health priorities among workers from occupational health clinic visit records: Experience from automobile industry in India. Journal of Family Medicine and Primary Care.

[19] Yulianti, E. (2008). Pengaruh Lingkungan Kerja Terhadap Kinerja Karyawan (Studi Kasus: RS. Juanda Kuningan).

[20] Jain. (2015). Knowledge management, leadership and decision making: A case of Academic Libraries.

[21] Danardono, I., \& Pribadi, F. (2016). Kinerja dan Motivasi Tenaga Medis: Studi Kasus Terhadap Pendapatan, Kompensasi dan Lingkungan Kerja Pada Rumah Sakit Umum Daerah Dr. Soedirman Kabupaten Kebumen, Jurnal Medicoeticolegal dan Manajemen Rumah Sakit, 5 (1), 63-72.

[22] Cormick (2017). How Motivation Works to Promote the Relationship Between Work Environment and Organizational Commitment to the Performance of Dharmasraya District Secretariat. J-MAS (Jurnal Manajemen dan Sains), 5(1), 10-19.

[23] Geckil. (2016). The relationship between organizational democracy perceptions and organizational psychological capital levels of physicians and nurses. International Journal of Recent Advances in Organizational Behaviour and Decision Sciences (IJRAOB), 2 (3), 818-835.

[24] Wardini, N.I. (2016). Pengaruh Gaya Kepemimpinan, Motivasi Kerja dan Kepuasan Kerja Terhadap Kinerja Pegawai (Studi Pada Pegawai RSUD dr.Soediran Mangun Sumarso Wonogiri.

[25] Mujeeb. (2011). Relationship between organizational culture and performance management practices: a case of university in Pakistan. Journal of Competitiveness, 3(4)

[26] Lousyiana, T. T., Harlen (2015). Pengaruh Gaya Kepemimpinan Dan Budaya Organisasi Terhadap Kepuasan Kerja dan Kinerja Perawat di Rumah Sakit Islam Ibnu Sina Pekanbaru, Jurnal Tepak Manajemen Bisnis, 7 (3), 509-521.

[27] Wahyuningsih, I. T., Nuraina, E., Amah, N. (2017). Pengaruh Budaya Organisasi dan Lingkungan Kerja Terhadap Produktivitas Kerja Karyawan Pada Rumah Sakit Paru Dungus Madiun, The 9th Forum Ilmiah Pendidikan Akuntansi, 5 (1), 9-81.

[28] Ghazzawi, I. A. (2017). Organizational turnaround: A conceptual framework and research agenda. American Journal of Management, 17(7), 9-23.

[29] Firmansyah, Erika, KA, Irwan, AM (2018). Studi Literatur: Analisis Gaya Kepemimpinan dan Kinerja Kepala Ruangan di Rumah Sakit, Jurnal Manajemen Kesehatan Yayasan R.S. Dr.Soetomo, 4(2), 71-81.

[30] Mangkunegara, A., Anwar P., (2005) Perilaku dan Budaya Organisasi, Bandung,PT Refika Aditama, Bandung.

[31] Sari, V.W.A., Sunaryo H., Khoirul, M. (2018). Pengaruh motivasi , Komitmen, dan Lingkungan Kerja Terhadap Kinerja Pegawai Pada Instansi Rumah Sakit Jiwa Dr. Radjiman Wediodiningrat Lawang, $e$ Jurnal Riset Manajemen Prodi Manajemen Fakultas Ekonomi Unisma, ebsite: www.fe.unisma.ac.id.

[32] Alrawahi (2020). The application of Herzberg's two-factor theory of motivation to job satisfaction in clinical laboratories in Omani hospitals. Heliyon, 6(9), e04829.

[33] Dousin. (2020). Does Person-Organization Fit (PO Fit) Mediate the Relationship Between Employee Job Satisfaction and Turnover Intention: The Case of Insurance Agents in Malaysia. International Journal of Human Resource Studies, 10(2), 117130-117130.

[34] Tasneem. (2017). Performance of female volunteer community health workers in Dhaka urban slums. Social science \& medicine (1982), 75(3), 511-515

[35] Goleman, Daniel, et.al. (2006). Primal Leadership: Leadership Based on Emotional Intelligence, Jakarta, PT.Gramedia Pustaka Utama.

[36] Ham, I., Verhoeven, A. (2009). Job satisfaction among general practitioners: A systematic literature review, 174-180.

[37] Hofstede (2005). Cultures and Organization, 2nd edition, New York, Mc Graw Hill.

[38] Kotter, John P., \& Heskett, James L. (2006) Corporate Culture and Performance, Translators Susi Diah Hardaniati \& Uyung Sulaksana, SAGA Publishers.

[39] Liker, K., Jeffrey (2013). Prinsip Manajemen dari Perusahaan Manufaktur Terhebat di Dunia; Jakarta: Penerbit Erlangga.

[40] Maxwell, John C., (2008) Mengembangkan Kepemimpinan Di dalam Diri Anda, Jakarta: Binarupa Aksara.

[41] Mullins, L. (2016). Management and Organizational Behavior, ninth edition, Pitman Publishing.

[42] Rivai,V. (2008). Kepemimpinan dan Perilaku Organisasi, Jakarta, PT. Raja Grafindo Persada. 
[43] Robbins \& Coulter. (2017) Manajemen, edisi 6, Jakarta, PT. Prenhallindo.

[44] Robbins, Stephen P., (2014) Perilaku Organisasi , edisi 12, Jakarta, PT. Indeks Kelompok Gramedia.

[45] Schein, E. (2010). Organizational Culture and Leadership, 4th edition, San Francisco: Josey Bass Publisher.

[46] Sumartini, N.M. (2009). Budaya Organisasi, Kepuasan Kerja dan Komitmen Dokter Spesialis di RSUD Kota Bekasi, Jurnal Kesehatan Masyarakat Nasional, 3 (6), 275-281.

[47] Susanto,A.B., Koesnadi,K.. Quantum Leader,Kepemimpinan dalam Dunia Bisnis dan Militer, PT.Gramedia

[48] Yukl, G. (2015). Kepemimpinan dalam Organisasi, edisi kelima, Jakarta: PT. Indeks. 